\title{
PELAKSANAAN MODEL PERFORMANCE ASSESSMENT DALAM \\ PEMBELAJARAN TAHSIN AL-QUR'AN DI PESANTREN DARUL MURSYIDI SIALOGO
}

\author{
Hilmi \\ ( Dosen PIAUD, Fakultas Agama Islam, UMTS ) \\ Email: Annahilmi92@gmail.com
}

\begin{abstract}
$\underline{\text { Abstract }}$
Implementation of teaching and learning process is inseparable from the components of learning, one of the components of the learning that is the evaluation / assessment. Assessments that match the application of the 2013 curriculum are authentic assessments that refer to a scientific approach. Authentic assessment is done comprehensively and based on the process of learning activities demonstrated by learners during the learning which is called performance assessment (performance assessment). Pesantren Darul Mursyidi Sialogo one of the schools that apply the performance assessment model in the learning of Qur'anic tahsin. The advantage of learning tahsin in Pesantren Darul Mursyidi Sialogo by using performance assessment model is by demanding learners to do related tasks of learning, and direct educator to give assessment when the learning process takes place, it is held every meeting in class. Learning tahsin in Pesantren Darul Mursyidi Sialogo including extracurricular activities, and take place every Saturday is held once a week. The existence of tahsin learning by using performance assessment model can improve reading skill of alQur'an learners according to tajwid rule. This is obtained based on the Qur'an reading test and learners' learning outcomes, from 269 students there are 20 unfinished learners.
\end{abstract}

Keywords: Performance Assessment Model, Learning Tahsin Al-Qur'an

\section{PENDAHULUAN}

Pendidikan merupakan suatu usaha untuk menghasilkan generasi yang mampu menjawab tantangan zaman dan menghadapi perubahan era globalisasi. Untuk menghadapi semua itu, tentu setiap manusia berusaha semaksimal mungkin memanfaatkan potensi yang ada di dalam dirinya. Melalui proses pendidikan maka potensi yang ada di dalam diri seseorang dapat digali dan dikembangkan. Sebagaimana pengertian pendidikan yang telah dijelaskan di dalam Undang-Undang Sistem Pendidikan Nasional Nomor 20 tahun 2003 Pasal 1 ayat 1 , yang berbunyi :

"Pendidikan adalah usaha sadar dan terencana untuk mewujudkan suasana belajar dan proses pembelajaran agar peserta didik secara aktif mengembangkan 
potensi dirinya untuk memiliki kekuatan spiritual keagamaan, pengendalian diri, kepribadian, kecerdasan, akhlak mulia, serta keterampilan yang diperlukan dirinya, masyarakat, bangsa, dan Negara”(Undang- undang RI Nomor 20 Tahun 2003: 2).

Berdasarkan Undang-Undang di atas landasan pemikiran pendidikan disusun sebagai usaha sadar yang memungkinkan bangsa Indonesia dalam mempertahankan kelangsungan hidup dan mengembangkan potensi dirinya secara terus-menerus dari suatu generasi ke generasi berikutnya. Pendidikan pada dasarnya adalah upaya untuk mempersiapkan peserta didik agar mampu hidup dengan baik dalam masyarakatnya, mampu mengembangkan dan meningkatkan kualitas hidup masyarakat dan bangsanya (Asmaun Sahlan, 2010: 1). Tercapai atau tidaknya tujuan pendidikan Nasional sebagaimana yang terdapat di dalam undang-undang di atas tidak terlepas dari proses pembelajaran.

Perubahan kurikulum KTSP menjadi Kurikulum 2013 menuntut pula perubahan pada standar penilaian. Penilaian memiliki kaitan yang penting dalam proses belajarmengajar dan dalam proses pendidikan. Penilaian yang cocok dengan penerapan kurikulum 2013 adalah penilaian autentik yang mengacu pada scientific approach. Penilaian autentik dilakukan secara komprehensif dan berdasarkan proses kegiatan belajar yang ditunjukkan oleh peserta didik selama pembelajaran berlangsung. Penilaian pembelajaran menggunakan authentic assesment yaitu penilaian yang menilai kesiapan peserta didik, proses, dan hasil belajar secara utuh (Fauziah, R, 2013: 165-178). Keterpaduan penilaian ketiga komponen tersebut akan menggambarkan kapasitas, gaya, dan perolehan belajar peserta didik bahkan mampu menghasilkan dampak instruksional (instructional effect) dan dampak pengiring (nurturant effect) dari pembelajaran. Salah satu jenis dari authentic assesment yaitu performance assessment atau penilaian kinerja ( Hamzah B Uno dan Satria Koni, 2012: 19). Menurut Stiggins performance assessment melibatkan peserta didik dalam aktivitas yang menunjukkan keterampilan-keterampilan tertentu dan atau menciptakan produk yang spesifik (Stiggins, R. J. 1994). A Muri Yusuf mengatakan performance assessment adalah penilaian berdasarkan hasil pengamatan penilai terhadap aktivitas peserta didik sebagaimana yang terjadi. Penilaian dilakukan terhadap unjuk kerja, tingkah laku, atau interaksi peserta didik (A Muri Yusuf, 2015: 296).

Performance assessment digunakan untuk menilai kemampuan peserta didik melalui penugasan. Penugasan tersebut dirancang khusus untuk menghasilkan respon (lisan atau tulis), menghasilkan karya (produk), atau menunjukkan penerapan 
pengetahuan. Tugas yang diberikan kepada peserta didik harus sesuai dengan kompetensi yang ingin dicapai dan bermakna bagi peserta didik. Penilaian unjuk kerja memiliki kelebihan dapat mengungkap potensi peserta didik dalam memecahkan masalah, penalaran, dan komunikasi dalam bentuk tulisan maupun lisan. Semua bentuk penilaian mempunyai lima komponen utama. Komponen-komponen itu adalah instrument penilaian, tanggapan peserta didik, penafsiran terhadap tanggapan peserta didik, pemberian skor, pencatatan hasil yang diperoleh dan pelaporan. Karakteristik asesmen unjuk kerja antara lain:

1. Menyusun respon sendiri

2. Berfikir pada tingkat yang lebih tinggi

3. Keautentikan tugas-tugas

4. Proses dan produk

5. Mengutamakan kedalaman bukan keluasan.

Penilaian unjuk kerja (performance assessment) diterapkan dalam pembelajaran tahsin al-Qur'an, karena pembelajaran tahsin menuntut peserta didik memiliki keterampilan dalam membaca dan menemukan contoh-contoh yang baru di dalam alQur'an. Dalam membaca al-Qur'an harus mengetahui ilmu tajwid, karena ilmu tajwid merupakan ilmu yang menuntut seseorang untuk bisa mengucapkan kalimat-kalimat alQur'an dengan tepat dan benar (Ahmad Munir dan Sudarsono, 1994: 8). Ilmu tajwid merupakan suatu cabang pengetahuan untuk mempelajari cara-cara membaca al-Qur'an. Allah swt. berfirman dalam surat Al-Muzammil: 4 yang berbunyi:

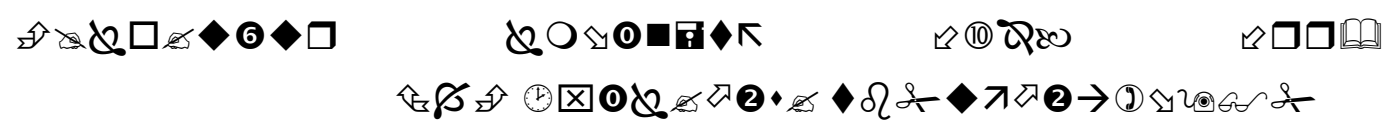

Artinya: "atau lebih dari seperdua itu, dan bacalah al-Qur'an itu dengan perlahan-lahan”. (Q.S. Al-Muzammil: 4)

Ahmad Mustafa al-Maraghi menafsirkan ayat di atas sebagai berikut: "bacalah al-Qur'an dengan perlahan, karena yang demikian itu lebih membantu untuk memahami dan menerangkannya (Ahmad Mustafa al-Maraghi, 1993: Jilid 2, 190). Lebih lanjut M. Quraish Shihab menjelaskan kata rattil dan tartila terambil dari kata ratala, ratala yang artinya serasi dan indah. Kamus-kamus bahasa merumuskan bahwa segala sesuatu yang baik dan indah dinamai ratl seperti gigi yang putih dan rapi, begitu juga dengan benteng yang kuat dan kokoh (M. Quraish Shihab, 2002: Vol. 14, 516). Menjaga atau 
memperhatikan tahsin al-Qur'an merupakan tanda bagusnya keimanan seseorang. Seorang muslim yang tidak berusaha memperbaiki bacaan al-Qur'an, maka keimanannya terhadap al-Qur'an sebagai kitab Allah swt. patut diragukan (Muhammad Zulaifan, 2016: 18). Karena bacaan yang bagus adalah cerminan rasa keyakinannya kepada kitab suci ini. Sesuai dengan ayat Q.S. al-Baqarah: 121 yang berbunyi:

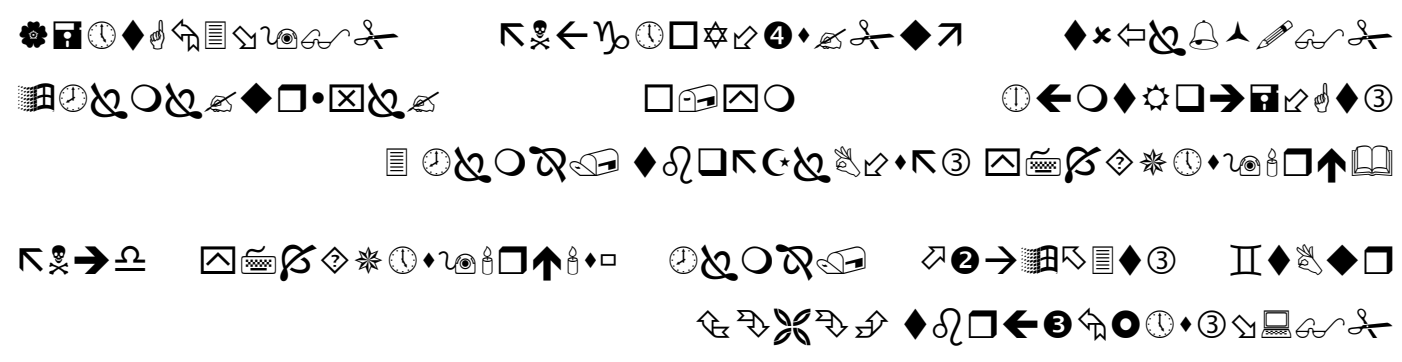

Artinya: "Orang-orang yang telah kami berikan Al Kitab kepadanya (Taurat dan Injil), mereka membacanya dengan bacaan yang sebenarnya, mereka itu beriman kepadanya. dan barangsiapa yang ingkar kepadanya, Maka mereka Itulah orang-orang yang rugi”. (Q.S. al-Baqarah: 121)

Kalimat yatluunahu haqqo tilawatih (mereka membacanya dengan bacaan yang sebenarnya) yakni membaca al-Kitab, Taurat, Injil. Redaksi yang mereka baca adalah redaksi kitab suci itu, mereka yang membaca dengan tekun sambil mempelajari secara sungguh-sungguh kandungannya, lalu mengikuti bacaan itu dengan pengalaman yang benar. Sesuai dengan dalil-dalil tersebut, wajar jika ulama mengatakan bahwa membaca al-Qur'an dengan tajwid itu wajib. Barangsiapa tidak berusaha membacanya dengan baik dan benar sesuai kaidah ilmu tajwid, maka ia berdosa. Membaca al-Qur'an dengan tahsin adalah sebuah keharusan. Siapa yang tidak mentajwidkan al-Qur'an maka ia berdosa, karena dengan tajwid Allah menurunkannya. Demikian juga al-Qur'an sampai kepada kita juga dengan tajwid.

Belajar al-Qur'an sudah harus dimulai semenjak usia anak-anak dan seterusnya, yang membutuhkan kesungguhan dan keseriusan hati, setelah pandai membaca al-Qur'an maka dianjurkan pula membacanya sesering mungkin. Karena bagi siapa yang sering membacanya apalagi dengan benar akan mendapat pahala dan termasuk amal yang sangat mulia (Zainal Abidin, 1992: 150). Pesantren Darul Mursyidi Sialogo adalah salah satu lembaga formal dalam mempelajari al-Qur'an. Pembelajaran yang diberikan kepada peserta didik dinamakan pembelajaran tahsin yaitu membaguskan atau memperbaiki bacaan. 
Salah satu sekolah yang menerapkan model performance assesment pada pembelajaran tahsin al-Qur'an adalah Pesantren Darul Mursyidi Sialogo. Berdasarkan observasi awal penulis, diketahui bahwa sekolah tersebut telah menerapkan model performance assesment pada pembelajaran tahsin al-Qur'an dibandingkan dengan sekolah umum setingkat SMP yang ada di Kota Padang. Ini terlihat dari guru yang mengajarkan tahsin al-Qur'an dengan menerapkan model performance assesment, di saat berlangsung proses pembelajaran guru tersebut mengajarkan kepada peserta didik beberapa ayat dengan tajwid yang benar, kemudian peserta didik disuruh kembali untuk membaca ayat. Setelah seluruh peserta didik selesai membaca, guru kembali menjelaskan tentang tajwid, setelah itu guru memberikan tugas kepada peserta didik. Kegiatan itu dilaksanakan setiap pelaksanaan pembelajaran tahsin al-Qur'an, serta penilaian dilaksanakan setiap kali pembelajaran. Berdasarkan wawancara yang penulis lakukan, bahwa peserta didik Pesantren Darul Mursyidi Sialogo pernah beberapa kali meraih penghargaan di bidang tahsin al-Qur'an.

Hal ini juga penulis ketahui dari dokumentasi yang penulis temukan di kantor sekolah seperti piala dan piagam penghargaan terhadap sekolah pada umumnya dan peserta didik pada khususnya. Keberhasilan peserta didik dalam membaca al-Qur'an dengan mahir dapat dilihat pada hasil belajar membaca al-Qur'an. Dari observasi awal yang penulis lakukan di Pesantren Darul Mursyidi Sialogo, dalam pembelajaran tahsin alQur'an dengan menggunaan model performance assesment mampu meningkatkan kemahiran baca al-Qur'an peserta didik. Maka dalam hal ini penulis tertarik melakukan penulisan lebih lanjut dengan judul "Pelaksanaan Model Performance Assessment dalam Pembelajaran Tahsin al-Qur'an di Pesantren Darul Mursyidi Sialogo.”

Secara umum, penelitian ini bertujuan untuk mengetahui bagaimana pelaksanaan pembelajaran tahsin al-Qur'an dengan menggunakan model performance assessment di Pesantren Darul Mursyidi Sialogo. Adapun secara khusus, tujuan penulisan ini untuk mengetahui:

1. Untuk mengidentifikasi perencanaan model performance assessment dalam pembelajaran tahsin al-Qur'an di Pesantren Darul Mursyidi Sialogo.

2. Untuk mengidentifikasi pelaksanaan model performance assessment dalam pembelajaran tahsin al-Qur'an di Pesantren Darul Mursyidi Sialogo.

3. Untuk mengidentifikasi evaluasi pembelajaran tahsin al-Qur'an dengan menggunakan model performance assessment di Pesantren Darul Mursyidi Sialogo.

Secara Teoritis hasil penelitian ini diharapkan memberikan sumbangan pemikiran atau dapat memberikan kontribusi yang berharga terhadap sekolah dan guru 
dalam pelaksanaan model performance assessment dalam pembelajaran tahsin al-Qur'an di Pesantren Darul Mursyidi Sialogo. Setelah penulisan ini selesai dilaksanakan, diharapkan hasilnya berguna sebagai:

a. Salah satu syarat mendapat gelar Magister pada Program Pascasarjana UIN Iman Bonjol Padang.

b. Mengembangkan wawasan penulis berkenaan dengan permasalahan yang dibahas, yaitu tentang pelaksanaan model performance assessment dalam pembelajaran tahsin al-Qur'an di Pesantren Darul Mursyidi Sialogo.

\section{METODE PENELITIAN}

Jenis penelitian merupakan penelitian lapangan (field research), yaitu penelitian yang dilakukan dalam kehidupan yang sebenarnya. Pada hakikatnya merupakan metode untuk menemukan secara spesifik dan realis tentang apa yang terjadi pada sesuatu saat di tengah-tengah masyarakat. Dengan memakai pendekatan kualitatif dengan metode deskriptif, serta menganalisis suatu peristiwa atau kejadian yang terjadi di lapangan sebagaimana adanya. Sumber data yang digunakan primer dan sekunder. Teknik pengumpulan data melalui observasi, wawancara dan dokumentasi, data yang dikumpulkan kemudian diolah dengan cara reduksi data, menyajikan data kemudian verifikasi data lalu ditarik kesimpulan dan dianalisis secara kualitatif, kemudian dilakukan uji keabsahan data dengan uji kredibilitas, transferability, realibilitas, kemudian kompirmability.

\section{HASIL PENELITIAN DAN PEMBAHASAN}

\section{A. Hasil Penelitian}

1. Perencanaan model performance assessment dalam pembelajaran tahsin alQur'an di Pesantren Darul Mursyidi Sialogo

Perencanaan dalam pembelajaran membantu pendidik dalam mengarahkan langkah dan aktivitas serta kinerja yang akan ditampilkan dalam pelaksanaan pembelajaran, untuk mencapai tujuan yang telah ditetapkan. Perencanaan dalam model performance assessment berdasarkan asumsi bahwa sebagian besar peserta didik dapat belajar dengan baik, dan guru mampu mengajarkan dengan baik, dengan demikian akan tercipta belajar mengajar yang efektif dan efisien. Melalui model performance assessment diharapkan berhasil membawa semua peserta didik kepada tujuan. Berdasarkan observasi penulis terlihat bahwa, dalam pembelajaran tahsin al-Qur'an, guru membuat perencanaan sebagai berikut: 
a. Mengidentifikasi pengetahuan dan keterampilan yang diharapkan dapat dimiliki oleh peserta didik setelah menyelesaikan tugas.

Untuk mengidentifikasi pengetahuan dan keterampilan yang dimiliki oleh peserta didik, maka harus dimulai dengan membuat perencanaan pembelajaran. Perencanaan dalam pembelajaran dibuat sesuai dengan tujuan yang ditetapkan. Secara teoritis ada empat komponen dalam menetapkan tujuan pembelajaran, yakni adanya peserta didik, tingkah laku, keadaan, serta perbandingan. Maka tujuan dalam pembelajaran tahsin al-Qur'an dengan menggunakan model performance assessment adalah untuk menciptakan peserta didik yang pandai dan bagus dalam membaca al-Qur'an, sehingga berdampak terhadap kemahiran dalam membaca al-Qur'an. Melalui observasi penulis, salah satu perencanaan dalam model performance assessment adalah untuk melihat sejauh mana kemampuan peserta didik pandai dan mahir dalam baca tulis al-Qur'an, mempunyai keterampilan dalam membaca al-Qur'an setelah proses pembelajaran itu dilaksanakan.

b. Merancang tugas-tugas yang dapat mengevaluasi kemampuan berpikir dan keterampilan peserta didik.

Sebagai seorang guru, harus mampu menjalankan tugasnya dengan sebaik-baiknya. Namun sebelum melaksanakan tugas, seorang guru harus membuat perencanaan, salah satunya dengan merancang bentuk tugas yang akan diberikan kepada peserta didik, sehingga dengan adanya tugas yang diberikan kepada peserta didik, dapat meningkatkan kemampuan berfikir dan mengembangkan keterampilan yang dimiliki oleh peserta didik.

Sesuai dengan pengamatan yang penulis lakukan terhadap salah seorang guru dalam membuat perencanaan pembelajaran tahsin yakni dengan merancang serta mempersiapkan tugas-tugas yang ada dalam pembelajaran tahsin. Ini penulis amati ketika guru memberikan tugas kepada peserta didik dalam mencari contoh ikhfa hakiki dalam surah al-Baqarah, sebanyak huruf ikhfa yang ada. Tugas diberikan guru dalam waktu yang ditentukan, dan setelah itu, tugas peserta didik langsung dinilai oleh guru.

c. Membuat format penilaian berupa rubrik.

Format penilaian dalam suatu pembelajaran sangat diperlukan, karena dengan adanya penilaian maka dapat mengetahui keberhasilan yang dicapai oleh peserta didik. Dalam model Performance assessment format penilaian dibuat dalam bentuk rubrik. Rubrik merupakan suatu pedoman penskoran 
yang digunakan untuk menentukan tingkat keberhasilan peserta didik dalam mengerjakan tugas. Di dalam suatu rubrik, guru mendeskripsikan masingmasing tingkat kemahiran peserta didik untuk setiap kriteria. Bentuk rubrik yang digunakan oleh guru tahsin al-Qur'an:

Tabel 1.1

\section{Bentuk Penilaian}

\begin{tabular}{|l|l|l|l|l|}
\hline No & \multicolumn{1}{|c|}{ Aspek Penilaian } & \multicolumn{3}{|c|}{ Skor } \\
\cline { 3 - 5 } & & $\mathrm{A}=20$ & $\mathrm{~B}=15$ & $\mathrm{C}=10$ \\
\hline 1 & $\begin{array}{l}\text { Pengucapan huruf } \\
\text { hijaiyah }\end{array}$ & & & \\
\hline 2 & Praktek membaca & & & \\
\hline 3 & Menulis & & & \\
\hline 4 & Mengerjakan tugas & & & \\
\hline 5 & Kemahiran membaca & & & \\
\hline & Skor penilaian & & & \\
\hline & Skor maksimal & & & \\
\hline
\end{tabular}

\section{Kriteria Nilai:}

A = 75 - 100 : Baik Sekali

$B=60-69$ : Cukup

$C=\imath 60:$ Kurang

2. Pelaksanaan model performance assessment dalam pembelajaran tahsin alQur'an di Pesantren Darul Mursyidi Sialogo

Dalam pelaksanaan pembelajaran, seorang guru dituntut untuk menciptakan suasana keakraban dengan peserta didik, mampu mengatasi problema-problema kelas yang muncul dan harus dihadapi dengan bijak serta menciptakan suasana persatuan dan kekeluargaan antar sesama. Adapun langkah- 
langkah yang perlu diperhatikan dalam pelaksanaan model performance assessment, antara lain:

a. Menentukan semua langkah atau aspek yang diperlukan yang akan mempengaruhi hasil belajar

b. Menuliskan kemampuan-kemampuan khusus yang diperlukan untuk menyelesaikan tugas

c. Mengusahakan kemampuan yang dapat diukur dengan tidak terlalu banyak, sehingga semua dapat diamati

d. Mengurutkan kemampuan yang akan diukur berdasarkan urutan yang akan diamati.

Pembelajaran tahsin al-Qur'an yang dilaksanakan di Pesantren Darul Mursyidi Sialogo merupakan pembelajaran ekstrakurikuler yang harus diikuti oleh semua peserta didik. Semua peserta didik wajib menuntaskan pembelajaran tahsin selama berada di Pesantren Darul Mursyidi Sialogo. Pelaksanaan pembelajaran tahsin dengan menggunakan model performance assessment sangat memberikan dampak positif terhadap kemahiran peserta didik dalam membaca ayat-ayat Allah.

Berdasarkan observasi yang penulis lakukan terhadap pelaksanaan pembelajaran tahsin al-Qur'an, terlihat bahwa guru melakukan langkah-langkah sebagai berikut:

1) Guru menentukan semua langkah dan aspek yang diperlukan yang akan mempengaruhi hasil belajar.

Dalam pembelajaran tahsin al-Qur'an, langkah awal yang dilakukan guru adalah menentukan aspek yang akan dinilai, sehingga berdampak terhadap hasil belajar peserta didik. Dalam hal ini penulis melihat keadaan peserta didik dalam mengikuti pembelajaran tahsin, baik dari segi mendengar, membaca, dan menulis. Karena setiap pelaksanaan pembelajaran tahsin, ketiga hal tersebut pasti dilakukan. Awalnya guru menentukan surah dan ayat yang akan dipelajari, kemudian guru membacakan ayat beberapa kali, dan selanjutnya peserta didik disuruh membaca ayat tersebut secara bergantian.

2) Menuliskan kemampuan-kemampuan khusus yang diperlukan untuk menyelesaikan tugas.

Kemampuan-kemampuan yang ada pada peserta didik dibagi kepada dua, yaitu kemampuan umum dan kemampuan khusus. Kemampuan umum adalah kemampuan berupa potensi yang bersifat umum, biasanya kemampuan 
umum berkenaan dengan kemampuan intelektual seseorang. Misalnya menyanyi, menggambar. Kemampuan khusus (talent) adalah kemampuan bawaan berupa potensi khusus dan jika memperoleh kesempatan berkembang dengan baik, akan muncul sebagai kemampuan khusus dalam bidang tertentu sesuai potensinya. Kemampuan khusus adalah seperangkat nilai yang dianggap sebagai tanda kemampuan individu untuk menerima latihan atau respon, seperti kemampuan berbahasa, musik, berhitung, mekanik, olahraga, dan sebagainya. Jadi, kemampuan merupakan potensi alamiah untuk memperoleh pengetahuan dan keterampilan, baik yang bersifat umum maupun khusus.

Kemampuan umum yang dimiliki oleh peserta didik bisa penulis amati dari hasil ulangan peserta didik dalam menuliskan ayat-ayat al-Qur'an. Ketika penulis melihat ada beberapa orang peserta didik yang memiliki kemampuan tersebut. Untuk mengembangkan kemampuan yang dimiliki oleh peserta didik tersebut, maka mereka dibina dalam kegiatan ekstrakurikuler yang berupa kaligrafi, latihan ini dilakukan satu kali dalam satu minggu yakni pada hari jum'at siang jam 13.00-15.00 WIB. Sedangkan kemampuan khusus terlihat dari beberapa orang peserta didik yang mempunyai keindahan suara dalam membaca al-Qur'an, sehingga peserta didik tersebut dikelompokkan dalam program binaan tilawah agar mereka bisa mengembangkan potensi yang ada pada dirinya. Khusus peserta didik yang memiliki kemampuan ini dimasukkan ke dalam lokal binaan tilawah yang berjumlah 11 orang.

Ini penulis lihat dari apa yang diajarkan oleh guru yang sedang mengajarkan hukum mim mati. Awalnya guru menjelaskan pengertian dan memberikan contoh terhadap ikhfa syafawi, kemudian guru menyuruh peserta didik untuk dapat mencari contoh ikhfa syafawi yang ada dalam surat tertentu dan waktu yang ditentukan. Dengan memberikan tugas seperti ini, maka diharapkan peserta didik dapat menuliskan contoh-contoh ikhfa syafawi yang ada dalam surah tertentu, dan setiap latihan yang diberikan, langsung dinilai oleh guru masing-masing.

Contoh salah satu program guru tahsin dalam menetukan kemampuan-kemampuan khusus peserta didik yang diperlukan untuk menyelesaikan tugas.

Tabel 1.2 


\begin{tabular}{|c|c|l|}
\hline No & Materi & \multicolumn{1}{|c|}{ Keterangan } \\
\hline 1 & $\begin{array}{c}\text { Ikhfa } \\
\text { Hakiki }\end{array}$ & $\begin{array}{l}\text { Peserta didik mencari contoh sebanyak } \\
\text { huruf ikhfa yang ada dalam waktu } \\
\text { yang ditentukan. Masing-masing } \\
\text { peserta didik mencari dua buah contoh } \\
\text { dalam satu huruf, satu nun mati dan } \\
\text { satu tanwin. ini berarti dalam ikhfa } \\
\text { hakiki peserta didik mencari contoh } \\
\text { sebanyak 30 buah. }\end{array}$ \\
\hline 2. & $\begin{array}{l}\text { Izhar } \\
\text { Halqi }\end{array}$ & $\begin{array}{l}\text { Peserta didik mencari contoh sebanyak } \\
\text { huruf izhar halqi, dalam waktu yang } \\
\text { ditentukan, masing-masing peserta } \\
\text { didik mencari dua contoh dalam satu } \\
\text { huruf, satu nun mati dan satu tanwin, } \\
\text { maka dalam tugas izhar halqi, peserta } \\
\text { didik mencari contoh sebanyak 12 } \\
\text { buah. }\end{array}$ \\
\hline 3. & $\begin{array}{c}\text { Idgham } \\
\text { Bighunn } \\
\text { ah }\end{array}$ & $\begin{array}{l}\text { Masing-masing peserta didik mencari } \\
\text { contoh sebanyak delapan buah, empat } \\
\text { nun mati, dan empat tanwin. }\end{array}$ \\
\hline 4. & $\begin{array}{l}\text { Idgham } \\
\text { Bilaghu } \\
\text { nnah }\end{array}$ & $\begin{array}{l}\text { Semua peserta didik membuat contoh } \\
\text { sebanyak empat buah dalam waktu } \\
\text { yang ditentukan. }\end{array}$ \\
\hline 5. & $\begin{array}{l}\text { Iqlab } \\
\text { Peserta didik disuruh mencari contoh } \\
\text { iqlab di dalam surah al-Mulk }\end{array}$ \\
\hline
\end{tabular}

Dokumentasi salah seorang guru tashin dalam mempersiapkan beberapa soal untuk melatih peserta didik dalam menciptakan keterampilan dalam membaca al-Qur'an

3) Mengusahakan kemampuan yang akan diukur tidak terlalu banyak, sehingga dapat diamati oleh peserta didik.

Berdasarkan pengamatan penulis, terlihat bahwa dalam pembelajaran tahsin al-Qur'an, guru selalu menilai peserta didik terhadap satu topik atau bahasan yang dipelajari hari itu, setiap pelaksanaan tahsin diadakan latihan untuk mengukur kemampuan peserta didik dalam satu topik atau bahasan. Ini dilakukan guru agar semua peserta didik dapat menguasai ilmu tajwid yang telah dipelajari. Peserta didik dituntut bagus dalam bacaan dan juga paham terhadap kaidah tajwid.

Hasil wawancara penulis dengan salah seorang guru tahsin menambahkan bahwa: Dalam pelaksanaan pembelajaran tahsin Penilaian dilakukan setiap kali pertemuan, setelah guru menerangkan pembelajaran, maka peserta didik diberi latihan, dengan tujuan agar mampu mengukur kemampuan peserta didik yang berhasil menguasai dalam setiap 
pembelajaran. Penilain ini dilakukan secara kontiniu, sehingga setiap keberhasilan peserta didik dalam pembelajaran dapat diamati.

4) Mengurutkan kemampuan yang akan diukur berdasarkan urutan yang akan diamati.

Tujuan dari suatu pembelajaran adalah bagaimana peserta didik dapat menguasai apa yang telah diajarkan. Dalam pelaksanaan pembelajaran dengan model performance assessment, seorang guru harus mengukur kemampuan yang dimiliki oleh peserta didik berdasarkan urutan materi yang telah dipelajari. Ketika penulis mengamati tentang penilaian yang dilakukan oleh guru, terlihat bahwa untuk mengukur kemampuan peserta didik, guru memberikan beberapa soal berdasarkan urutan materi yang dipelajari. Sebagai contoh, dalam mengukur kemampuan yang dimiliki oleh peserta didik, guru memulai dengan memberi soal terhadap hukum nun mati atau tanwin, yang terdiri dari lima bagian, yakni ikhfa hakiki, izhar halqi, idgham bigunnah, idgham bilaghunnah, serta iqlab, kemudian hukum mim mati, yang terdiri dari ikhfa syafawi, idgham mimi, serta izhar syafawi. Penilaian seperti ini dilakukan setelah pembelajaran selesai dilaksanakan. Dan penilaian ini dilakukan dengan cara menyuruh peserta didik mencari contoh masing-masing dari poin di atas, sehingga dari hasil pelaksanaan itu terlihat kemampuan masing-masing peserta didik.

\section{Evaluasi pembelajaran tahsin al-Qur'an dengan menggunakan model} performance assessment di Pesantren Darul Mursyidi Sialogo

Evaluasi berarti pengumpulan kenyataan secara sistematis untuk menetapkan apakah dalam kenyataannya terjadi perubahan dalam diri peserta didik dan menetapkan sejauh mana tingkat perubahan dalam diri peserta didik.

Tujuan evaluasi adalah untuk menghimpun keterangan yang akan dijadikan sebagai bukti mengenai taraf perkembangan atau taraf kemajuan yang dialami oleh para peserta didik setelah meraka mengikuti proses pembelajaran dalam jangka waktu tertentu. Serta menghimpun informasi yang dijadikan dasar untuk mengetahui taraf kemajuan, taraf perkembangan, taraf pencapaian kegiatan belajar peserta didik.

Evaluasi dalam model performance assessment dilaksanakan mulai dari awal proses pembelajaran sampai selesai. Guru tidak hanya mengukur kemampuan peserta didik pada hasil akhir pembelajaran, melainkan penilaian itu mencakup seluruh aspek, yakni diagnostik, sumatif, dan formatif. 


\section{Evaluasi Diagnostik}

Evaluasi diagnostik dilakukan guru untuk mengetahui jenis kesukaran yang dihadapi oleh peserta didik dalam suatu mata pelajaran tertentu. Tes diagnostik memfokuskan tujuannya pada pencarian letak kesulitan peserta didik dalam mempelajari suatu materi pelajaran sehingga pembelajaran perbaikan yang akan diberikan dapat menjadi lebih efektif menuju letak permasalahan belajar yang dialami oleh peserta didik.

Ini terlihat ketika penulis mengamati evaluasi yang dilakukan oleh guru tahsin, sebelum pembelajaran dimulai, guru memberikan pertanyaanpertanyaan yang menyangkut dengan pembelajaran sebelumnya. Contoh pada topik pembelajaran hukum nun mati, namun sebelum mengajarkan hukum mim mati, guru terlebih dahulu menanyakan tentang apa saja yang termasuk kepada hukum nun mati beserta contoh. Dengan demikian dapat dipahami bahwa tes diagnostik dilakukan untuk menentukan apakah bahan prasyarat telah dikuasai atau belum oleh peserta didik, serta untuk meningkatkan penguasaan peserta didik terhadap bahan telah dipelajari.

2. Evaluasi formatif

Evaluasi formatif adalah evaluasi yang dilakukan pada setiap akhir pembahasan suatu pokok bahasan/topik, dan dimaksudkan untuk mengetahui sejauh mana suatu proses pembelajaran telah berjalan sebagaimana yang direncanakan. Winkel menyatakan bahwa yang dimaksud dengan evaluasi formatif adalah penggunaan tes-tes selama proses pembelajaran yang masih berlangsung, agar peserta didik dan gurumemperoleh informasi (feedback) mengenai kemajuan yang telah dicapai.

Evaluasi formatif dilaksanakan untuk mengetahui seberapa jauh tujuan yang ditetapkan telah tercapai. Dari hasil evaluasi ini akan diperoleh gambaran siapa saja yang telah berhasil dan siapa yang dianggap belum berhasil untuk selanjutnya diambil tindakan-tindakan yang tepat. Tindak lanjut dari evaluasi ini adalah bagi para peserta didik yang belum berhasil maka akan diberikan remedial, yaitu bantuan khusus yang diberikan kepada peserta didik yang mengalami kesulitan memahami suatu pokok bahasan tertentu. Sementara bagi peserta didik yang telah berhasil akan melanjutkan pada topik berikutnya, bahkan bagi mereka yang memiliki kemampuan yang lebih akan diberikan pengayaan, yaitu materi tambahan yang sifatnya perluasan dan pendalaman dari topik yang telah dibahas. 
Dari hasil observasi yang penulis lakukan, terlihat bahwa dalam setiap pembelajaran, guru selalu memberikan tugas kepada peserta didik setelah materi pembelajaran diterangkan oleh guru. Dalam setiap topik pembahasan yang diajarkan oleh guru, peserta didik harus mencatat terlebih dahulu, dan kemudian dalam waktu 25 menit terakhir, maka peserta didik diberi tugas untuk mencari contoh terhadap topik yang dipelajari. Semua peserta didik dituntut harus bisa mengerjakan latihan tersebut dalam waktu yang telah ditentukan.

3. Evaluasi Sumatif

Evaluasi sumatif adalah evaluasi yang dilakukan pada setiap akhir satu satuan waktu yang di dalamnya tercakup lebih dari satu pokok bahasan, dan dimaksudkan untuk mengetahui sejauhmana peserta didik telah dapat berpindah dari suatu unit ke unit berikutnya. Untuk mengetahui pelaksanaan evaluasi sumatif, penulis melakukan wawancara dengan salah seorang guru tahsin: Evaluasi sumatif dalam pembelajaran tahsin al-Qur'an selalu di adakan, baik evaluasi tengah semester, ataupun evaluasi semester, selalu kami lakukan. Evaluasi ini kami lakukan, dengan maksud untuk melihat ketuntasan belajar peserta didik selama mengikuti pembelajaran. Evaluasi ini dilakukan terhadap semua materi yang telah dipelajari, baik itu membaca, menulis, maupun penguasaan tajwid selama pembelajaran berlangsung, dan yang lebih penting bagaimana peserta didik itu mampu dalam membaca ayatayat Allah dengan kaidah tajwid yang benar. Namun yang unik di SMP N 30 ini, bagi peserta didik yang tidak tuntas dalam evaluasi akhir semester, maka peserta didik tersebut akan mengulang pembelajaran tahsin pada tahun berikutnya, sekalipun dia sudah naik ke kelas IX.

Kemudian salah seorang guru tahsin menjelaskan bahwa: Evaluasi semester dan tahunan dalam pembelajaran tahsin, selalu dilaksanakan. Evaluasi ini bertujuan untuk mengukur kemampuan peserta didik selama pelaksanaan proses pembelajaran. Bagi peserta didik yang tidak lulus dalam ujian semester dan tahunan, maka akan mengulang tahun depan, kerena sesuai dengan aturan yang ditetapkan oleh sekolah. Berdasarkan uraian di atas dapat dipahami bahwa, evaluasi dalam pembelajaaran tahsin al-Qur'an dilakukan dengan tiga tahap yaitu evaluasi diagnostik, evaluasi formatif, dan evaluasi sumatif. Evaluasi diagnostik dilakukan setiap awal pembelajaran, dengan cara mendiagnosa kemampuan peserta didik terhadap pelajaran yang 
telah lalu dengan memberikan beberapa pertanyaan, sedangkan evaluasi formatif dilakukan setelah guru menerangkan suatu topik dalam setiap pelaksanaan pembelajaran, serta evaluasi sumatif dilakukan setiap tengah semester, semester, serta tahunan, evaluasi ini dilakukan untuk mendapatkan hasil terhadap ketuntasan peserta didik selama proses pembelajaran berlangsung.

Adapun alat-alat yang dipakai dalam evaluasi model performance assessment di Pesantren Darul Mursyidi Sialogo adalah sebagai berikut:

1) Paper and pencil test (tes tulis)

Merupakan serangkaian pertanyaan yang harus dijawab oleh peserta didik secara tertulis untuk mengukur kepahaman mereka terhadap suatu materi pembelajaran. Hal tersebut sesuai dengan observasi yang penulis lakukan, terlihat bahwa: dalam pembelajaran semua peserta didik membawa alat tulis yang digunakan dalam proses pembelajaran.

Kemudian penulis melakukan wawancara dengan salah seorang guru tahsin: Dalam setiap pembelajaran tahsin al-Qur'an selalu diadakan evaluasi, ini bertujuan agar setiap pelaksanaan pembelajaran bisa memantau keberhasilan dan kemajuan peserta didik dalam membaca alQur'an. Evaluasi ini dilakukan dengan cara test tertulis, yang mana guru menyuruh peserta didik menulis beberapa ayat yang telah dibaca sesuai dengan tajwid yang benar, kemudian tulisan peserta didik itu langsung diperiksa dan dinilai oleh guru yang bersangkutan, ini bertujuan agar setiap pembelajaran peserta didik mengetahui kemajuan yang ada pada dirinya.

Senada dengan hal di atas, penulis juga menanyakan kepada salah seorang peserta didik tentang evaluasi yang dilakukan oleh guru dalam pembelajaran tahsin al-Qur'an, bahwa: Dalam setiap pelaksanaan pembelajaran tahsin al-Qur'an, kami selalu diberi tugas oleh guru setelah selesai membaca al-Qur'an secara bergiliran, kami disuruh untuk menulis beberapa ayat yang telah dibaca sebelumnya bersamaan dengan tajwid yang telah diajarkan guru, kemudian setiap latihan kami selalu diperiksa oleh guru, dan diakhir pembelajaran guru menjelaskan kepada kami 
tentang hal-hal yang harus diulang dan dipelajari untuk pertemuan selanjutnya, agar selalu dapat meningkatkan kemahiran dalam membaca al-Qur'an.

2) Performance test (tes kerja)

Tes ini dipakai untuk mengukur kinerja atau skill yang merupakan manifestasi dari pengetahuan ide, konsep dan keterampilan yang bisa diamati. Di lembaga ini tes ini berupa tes lisan. Ini sesuai dengan hasil observasi penulis terlihat bahwa evaluasi dalam pembelajaran tahsin, dilakukan dengan cara lisan, maksudnya setiap peserta didik mampu membaca surah dan ayat yang telah ditentukan oleh guru. Setiap peserta didik, disuruh untuk membaca surah dan ayat yang berbeda dengan teman sebelumnya, dan semuanya mendapat giliran masing-masing.

3) Product tes (hasil karya)

Dengan product tes ini dapat diketahui sejauh mana tingkat kreatifitas dan kemampuan berfikir peserta didik dalam mengorganisasikan gagasan-gagasan kedalam bentuk kongkrit (nyata). Dalam tes ini yaitu berupa hasil tulisan para peserta didik. Selain penilaian yang dilakukan dilakukan diakhir periode, penilaian juga dilakukan saat proses pembelajaran tersebut. Adapun penilaian yang dinilai dari sikap peserta didik, tulisan, produk. Sikap yang dinilai dari peserta didik itu sendiri meliputi aspek-aspek berikut ini:

(a) Keaktifan peserta didik saat mengikuti pembelajaran

(b) Kreatifitas peserta didik dalam melakukan praktek menulis

(c) Perhatian peserta didik saat mendengarkan materi dari guru

(d) Kemampuan peserta didik saat berkomunikasi dengan guru maupun dengan teman-temannya.

Berdasarkan wawancara yang penulis lakukan dengan salah seorang guru tahsin, menjelaskan bahwa: Evaluasi dalam product tes bertujuan untuk melihat kemampuan berfikir peserta didik dalam mengorganisasikan gagasan-gagasan kedalam bentuk nyata. Dalam hal ini, penilaiannya lebih ditekankan kepada penilaian sikap peserta didik, baik keaktifan peserta didik dalam mengikuti pembelajaran, keaktifan peserta didik dalam melakukan praktek menulis, perhatiaan 
peserta didik saat mendengarkan materi dari guru, serta kemampuan peserta didik saat berinteraksi dengan guru dan sesama teman.

Dengan demikian dapat penulis simpulkan bahwa alat tes yang dipakai dalam pembelajaran tahsin al-Qur'an dengan menggunakan model performance assessment yaitu, paper and pencil test (tes tulis), performance test (tes kerja), serta product tes (hasil karya).

Berdasarkan uraian di atas dapat penulis simpulkan bahwa secara metodologi pelaksanaan evaluasi yang diterapkan dalam pembelajaran tahsin al-Qur'an di SMPN 30 Padang memiliki kesamaan dengan model performance assessment, karena penilaian dilaksanakan setiap kali pertemuan dengan menilai kinerja peserta didik dari tugas-tugas yang diberikan. Evaluasi yang dilakukan oleh guru dalam pembelajaran tahsin Al-Qur'an sama halnya dengan mata pelajaran lain, yaitu dengan menggunakan tes diagnostik, sumatif, dan formatif, sehingga dengan adanya evaluasi tersebut, maka dapat meningkatkan kemahiran peserta didik dalam membaca al-Qur'an, serta menggunakan alat-alat yang ada dalam model performance assessment.

\section{B. Pembahasan}

Sesuai dengan judul dari tesis ini dimaksudkan, bahasan yang dilakukan untuk menganalisis berbagai fenomena yang ditemukan baik melalui observasi, wawancara dan studi dokumentasi di SMPN 30 Padang. Pembelajaran tahsin alQur'an di Pesantren Darul Mursyidi Sialogo dengan menggunakan model performance assessment berjalan dengan lancar, ini terbukti karena proses belajar mengajar yang dilaksanakan mempunyai perencanaan, sehingga pelaksanaan dan evaluasi berjalan sesuai harapan. Al-Qur'an merupakan kalam Allah yang berfungsi sebagai pedoman hidup dan petunjuk bagi manusia dalam menaungi kehidupan dunia menuju kehidupan yang abadi di akhirat kelak. Mempelajari al-Qur'an merupakan kewajiban setiap umat Islam. Al-Qur'an bukan hanya sekedar untuk dibaca, dihafal atau di musabaqahkan, tetapi yang jauh lebih penting bagaimana kita bisa mengamalkan isi al-Qur'an itu dalam kehidupan sehari-hari.

Berdasarkan hasil penelitian yang peneliti lakukan di Pesantren Darul Mursyidi Sialogo tentang pembelajaran tahsin al-Qur'an dengan menggunakan model performance assessment yang akan ditinjau dari segi perencanaan, 
pelaksanaan, dan evaluasi. Perencanaan model performance assessment dalam pembelajaran tahsin al-Qur'an dengan menetapkan tujuan pembelajaran, mengidentifikasi pengetahuan dan keterampilan yang diharapkan dapat dimiliki oleh peserta didik setelah menyelesaikan tugas, merancang tugas-tugas yang dapat mengevaluasi kemampuan berpikir dan keterampilan peserta didik, membuat format penilaian berupa rubrik.

Pelaksanaan dalam model performance assessment dalam pembelajaran tahsin al-Qur'an sebagai berikut: guru menentukan semua langkah dan aspek yang diperlukan yang akan mempengaruhi hasil belajar, menuliskan kemampuankemampuan khusus yang diperlukan untuk menyelesaikan tugas, mengusahakan kemampuan yang akan diukur tidak terlalu banyak, sehingga dapat diamati oleh peserta didik, mengurutkan kemampuan yang akan diukur berdasarkan urutan yang akan diamati. Pelaksanaan evaluasi yang dilakukan dalam pembelajaran bersifat berkelanjutan yang bertujuan untuk melihat ketuntasan setiap kompetensi dasar, yang dapat ditinjau dari evaluasi diagnostik, evaluasi formatif, dan evaluasi sumatif.

Melalui perencanaan, pelaksanaan, serta evaluasi yang ada dalam pembelajaran tahsin al-Qur'an dengan menggunakan model performance assessment dapat meningkatkan kemahiran baca Al-Qur'an peserta didik. Karena kemahiran baca Al-Qur'an merupakan suatu perubahan yang terjadi dalam diri peserta didik, sebagai implikasi dari pengalaman dan aktivitas belajar, sehingga dapat mengkonstruksikan pengetahuan itu dalam kehidupan sehari-hari.

\section{PENUTUP}

\section{A. Kesimpulan}

Berdasarkan hasil penelitian di atas, maka penulis menyimpulkan beberapa hal, yaitu:

1. Perencanaan model performance assessment dalam pembelajaran tahsin al-Qur'an di Pesantren Darul Mursyidi Sialogo yang diterapkan guru sebagai berikut: Pertama mengidentifikasi pengetahuan dan keterampilan yang diharapkan dapat dimiliki oleh peserta didik setelah menyelesaikan tugas. Untuk mengidentifikasi pengetahuan dan keterampilan yang dimiliki oleh peserta didik, maka harus dimulai dengan membuat perencanaan pembelajaran. Perencanaan dalam pembelajaran dibuat sesuai dengan tujuan yang ditetapkan. Kedua merancang tugas-tugas yang dapat mengevaluasi kemampuan berpikir dan keterampilan peserta didik. Seorang guru harus membuat perencanaan, salah satunya dengan merancang bentuk tugas yang akan diberikan kepada peserta didik, sehingga 
dengan adanya tugas yang diberikan kepada peserta didik, dapat meningkatkan kemampuan berfikir dan mengembangkan keterampilan yang dimiliki oleh peserta didik. Ketiga membuat format penilaian berupa rubrik, dalam model Performance assessment format penilaian dibuat dalam bentuk rubrik, di dalam suatu rubrik, guru mendeskripsikan masing-masing tingkat kemahiran peserta didik untuk setiap kriteria.

2. Pelaksanaan model performance assessment dalam pembelajaran tahsin al-Qur'an di Pesantren Darul Mursyidi Sialogo, dimulai dari guru menentukan semua langkah dan aspek yang diperlukan untuk mempengaruhi hasil belajar, menuliskan kemampuan-kemampuan khusus yang diperlukan untuk menyelesaikan tugas, mengusahakan kemampuan yang akan diukur tidak terlalu banyak, sehingga dapat diamati oleh peserta didik, mengurutkan kemampuan yang akan diukur berdasarkan urutan yang akan diamati.

3. Evaluasi pembelajaran tahsin al-Qur'an dengan menggunakan model performance assessment di Pesantren Darul Mursyidi Sialogo menggunakan 3 bentuk evaluasi yaitu: Pertama evaluasi diagnostik, evaluasi diagnostik dilakukan guru untuk mengetahui jenis kesukaran yang dihadapi oleh peserta didik dalam suatu mata pelajaran tertentu, sebelum pembelajaran dimulai, guru memberikan pertanyaanpertanyaan yang menyangkut dengan pembelajaran sebelumnya. Kedua evaluasi formatif dilaksanakan untuk mengetahui seberapa jauh tujuan yang ditetapkan telah tercapai. Dari hasil evaluasi ini akan diperoleh gambaran siapa saja yang telah berhasil dan siapa yang dianggap belum berhasil untuk selanjutnya diambil tindakan-tindakan yang tepat. Ketiga evaluasi sumatif dilakukan pada setiap akhir satu satuan waktu yang di dalamnya tercakup lebih dari satu pokok bahasan, dan dimaksudkan untuk mengetahui sejauhmana peserta didik telah dapat berpindah dari suatu unit ke unit berikutnya. Sedangkan bentuk tesnya yaitu paper and pencil test (tes tulis), performance test (tes kerja), product tes (hasil karya).

\section{B. Saran}

1. Guru tahsin al-Qur'an

Salah satu penentu keberhasilan pembelajaran adalah guru, jika guru mapan dalam perencanaan memilih metode, media, dan penilaian yang tepat tentu akan melahirkan peserta didik yang berkemampuan dalam membaca al-Qur'an dengan baik,

2. Bagi peserta didik 
a.Hendaknya peserta didik Pesantren Darul Mursyidi Sialogo terus menerus mengikuti pembelajaran tahsin al-Qur'an dan menerapkannya dalam kehidupan sehari-hari

b. Hendaknya bisa lebih meningkatkan lagi pengetahuannya dari segi membaca dan menulis al-Qur'an dengan baik dan benar.

c.Hendaknya bisa menjadi peserta didik yang pengetahuan dan pemahahannya banyak tentang al-Qur'an

3. Hendaknya orang tua memotivasi dan membimbing anaknya untuk mengikuti dan menekuni pembelajaran tahsin al-Qur'an.

\section{DAFTAR PUSTAKA}

Abdullah, A. G. Fauziah, R., \& Hakim, D. L. Pembelajaran Saintifik Elektronika Dasar Berorientasi Pembelajaran Berbasis Masalah, Jurnal Invotec, 2013

Abidin, Zainal, Seluk Beluk Al-Qur'an, Jakarta: Rineka Cipta, 1992

B Uno, Hamzah dan Satria Koni, Assesment Pembelajaran, Jakarta: Bumi Aksara, 2012

Munir, Ahmad dan Sudarsono, Ilmu Tajwid dan Seni Baca Al-Qur'an, Jakarta: Rineka Cipta, 1994

Mustafa al-Maraghi, Ahmad, Tafsir al-Maraghi, Jilid 29, Semarang: CV Toha Putra, 1993, cet. Ke 2

Sahlan, Asmaun, Mewujudkan Budaya Religius di Sekolah Upaya Mengembangkan PAI dari Teori Ke Aksi Yogyakarta: Menara Kudus, 2010

Shihab, M. Quraish, Tafsir al-Misbah, Vol. 14 Jakarta: Lentera Hati, 2002

Stiggins, R. J, Student-Centered Classroom Assessment, New York: Macmillan College Publishing Company, 1994

Stiggins, R. J, Student-Centered Classroom Assessment, New York: Macmillan College Publishing Company, 1994

Sugiyono, Metode Penelitian Kualitatif, kuantitatif, R\&D, Bandung: Alfabeta, 2012

, Metode Penelitian Pendidikan, Bandung: Alfabeta, 2014

Undang- undang RI Nomor 20 Tahun 2003 Tentang Sistem Pendidikan Nasional, Jakarta: Sinar Grafika, 2003

Yusuf,A Muri, Asesmen dan Evaluasi Pendidikan, Jakarta: Kencana, 2015296

Zulifan, Muhammad, Tajwid For All, Jakarta: Grasindo, 2016 
